\title{
Cell proliferation and interferon- $\gamma$ response to recombinant MBP-3, NarL, MT-10.3, and 16kDa Mycobacterium tuberculosis antigens in Brazilian tuberculosis patients
}

\author{
Ricardo Candido Oliveira Tavares, Jorge Salgado, Valéria Barbosa Moreira*, \\ Mônica Antonia S Ferreira, Fernanda Carvalho Queoz Mello**, Janaína AW Leung**, \\ Mahavir $\backslash$ Singh***, Leila de Souza Fonseca**, Maria Helena Feres Saad ${ }^{+}$
}

Departamento de Micobacterioses, Instituto Oswaldo Cruz- Fiocruz, Av. Brasil 4365, 21045-360 Rio de Janeiro, RJ, Brasil *Hospital Municipal Souza Aguiar, Rio de Janeiro, RJ, Brasil **Hospital Universitario, Instituto Microbiologia, UFRJ, Rio de Janeiro, RJ, Brasil ***Lionex Immuno Diagnostic and Therapeutic, Braunchweig, Germany

\begin{abstract}
Human pulmonary tuberculosis (TB) is a worldwide public health problem. In resistant individuals, control of the infection mainly requires development of a Th1 cell immune response with production of cytokines, of which interferon- $\gamma(I F N-\gamma)$ plays an important role. Several antigens from Mycobacterium tuberculosis complex has been described for use in vaccine development or for diagnostic purposes, however little evaluation has been done in endemic area for TB. The proliferative and IFN- $\gamma$ human $T$ cell immune responses, to four recombinant proteins (MBP-3, NarL, MT-10.3, $16 \mathrm{kDa}$ ) and PPD, of 38 Brazilian TB patients (6 untreated and 32 treated) and 67 controls (38 positive and 29 negative tuberculin skin test - TST) were compared. The highest reactivity mean rate was obtained with PPD followed by $16 \mathrm{kDa}$ in TB patients. While most of the patients (87\%) and controls (> 64\%) respond to the PPD, 16kDa was more specifically recognized (> 21\%) although less sensitive (54\%). When TB patients were divided according to treatment status, opposite to PPD, higher average level of IFN- $\gamma$ was induced by $16 \mathrm{kDa}$ in untreated $(505 \mathrm{pg} / \mathrm{ml})$ compared to treated TB patients and TST+ $(269.8$ $\mathrm{pg} / \mathrm{ml} \times 221.6 \mathrm{pg} / \mathrm{ml}$, respectively), although the difference was not significant. These data show that in contrast with the other recombinant proteins, the stimulatory potency of $16 \mathrm{kDa}$ to induce proliferative and INF- $\gamma$ response was more effective and is more recognized by active TB untreated patients, eliciting in control individuals a more selective immune response than PPD.
\end{abstract}

Key words: tuberculosis - $16 \mathrm{kDa}$ - MT10.3 - interferon- $\gamma$ - immune response

Mycobacterium tuberculosis is an extremely successful pathogen infecting a third of the world's population, the cases being concentrated in developing countries (WHO 2002, Guzmán et al. 2003). Koch bacillus, which is transmitted by respiratory route from person to person, invades macrophage, multiply and can remain latent within the lung granuloma for years. Disease control is based on early identification of infected individuals followed by appropriate treatment. Disease progression prevention through inducement of protective immunity may be achieved through vaccination; however the current available Bacillus Calmette-Guérin (BCG) efficacy is controversial (Colditz et al. 1994, Fine 1995).

Several studies have identified secreted proteins, which are considered important targets immune response

Financial support: Brazil $\times$ Germany Science and Technology Ministry Program grant number 52.0009/02-09, Projeto Milênio (CNPq), Faperj grant E-26/171.546/2002, John Hopkins University grant number 1U19AI45432-01 from the National Institutes of Health

${ }^{+}$Corresponding author: saad@ioc.fiocruz.br

Received 19 May 2006

Accepted 19 October 2006 recognition. However, little is known about the reactivity to these antigens in patients from Rio de Janeiro where are described the highest rates of tuberculosis (TB) incidence in Brazil (Hijjar 2005). The $16 \mathrm{kDa}$ molecule is a polypeptide belonging to the $\alpha$-cristallin family of low molecular weight, heat shock proteins, of which the coding gene (Rv2031c) has been found exclusively in the M. tuberculosis complex (Yuan et al. 1998). It has been reported as dominant protein produced in the static growth phase or under oxygen deprivation and required for bacterial replication inside macrophages (Yuan et al. 1998, Agrewala \& Wilkinson 1998). MBP-3 is a $23 \mathrm{kDa}$ maltose binding protein found as residue in the purification process of the MPT-64 antigen. The MT-10.3 or TB10.3 (Rv3019c) antigen, together with TB12.9 and TB10.4, comprise one subfamily within the esat- 6 gene family and seem to be expressed during the TB infection (Skjot et al. 2002, Demissie et al. 2006). Two regulatory system components are ubiquitously distributed among bacteria and plants and are involved in the organisms' virulence (Urao et al. 2000). Nar L is the product of the response regulator narL gene of $M$. tuberculosis regulatory system (Parish et al. 2003).

In the present study, we evaluated the production of interferon- $\gamma($ IFN- $\gamma)$ and the proliferative response of peripheral blood mononuclear cells (PBMC), from TB patients from Rio de Janeiro, stimulated with the 
following $M$. tuberculosis recombinant proteins: $16 \mathrm{kDa}$, MBP-3, MT-10.3, and NarL.

\section{MATERIALS AND METHODS}

Study subject - TB diagnosis was performed at district Hospital Souza Aguiar (HMSA), School-Center Germano Sinval de Farias of National Public Health School/Fundação Oswaldo Cruz, and University Hospital Clementino Fraga Filho (HU-UFRJ), Rio de Janeiro city, in the Southern region of Brazil. The criteria for TB diagnosis and standard treatment were in accordance with those of the Brazilian Ministry of Health (MS 2002). Patients and control groups are described in Table I. Pulmonary TB diagnosis was defined by at least one sputum-positive smear by Ziehl-Neelsen staining, a positive $M$. tuberculosis sputum culture or a compatible clinical evolution. The control groups were composed of biology students with positive tuberculin skin tests (TST, $\geq 5 \mathrm{~mm}$ ) or negative reaction $(<5 \mathrm{~mm})$ and no TB family history. None of the TB patients had clinical evidence of anti-TB chemotherapy failure or miliary TB. Patients under 18 years old and pregnant or breastfeeding women were not included. All recruited TB patients were negative by enzyme-linked immunosorbent assay (ELISA) for human immunodeficiency virus (HIV) (Organon Teknica, Boxtei, The Netherlands). Blood samples were collected after written informed consent was obtained. The study protocol was approved by the National Research Ethical Committee.

Mycobacterial antigens - M. tuberculosis recombinant in Escherichia coli 16kDa, MBP-3, MT10,3 and NarL were kindly provided by Lionex GmbH (Braunchweig, Germany). Purified protein derivative (PPD RT23) was purchased from the Staten Serum Institute (Copenhagen, Denmark). The recombinant Ags and phytohemaglutinin (PHA) mitogen were utilized in the in vitro assays in a final concentration of $5 \mu \mathrm{g} / \mathrm{ml}$, and PPD was employed in a final concentration of 2.5 $\mu \mathrm{g} / \mathrm{ml}$ (optimal concentrations were established in previous pilot experiments, data not shown).

Cellular proliferation assay - PBMC were isolated from heparinized venous blood by Ficoll-Hypaque density gradient centrifugation (Pharmacia, Uppsala, Sweden). The cells were ressuspended in RPMI-1640 supplemented with $0.04 \mathrm{mM}$ glutamine, $20 \%$ autologous heat-inactivated serum, $100 \mathrm{U} / \mathrm{ml}$ penicilin and streptomycin (Gibco, Paisley, UK). For cell culture, a total volume of $200 \mu \mathrm{l} / \mathrm{well}$ of PBMC $\left(1 \times 10^{6}\right.$ cells $\left./ \mathrm{ml}\right)$ was plated in triplicate in 96-well-round bottom microtitre plate (Costar Corp., Cambridge, MA) in the presence or absence of each $\mathrm{Ag}$, at $37^{\circ} \mathrm{C}$ in a humidified $5 \% \mathrm{CO}_{2}$ chamber for five days. Supernatants $(100 \mu \mathrm{l} /$ well for each triplicate) were pooled and stocked at $-20^{\circ} \mathrm{C}$ for further IFN- $\gamma$ quantification. T-cells were added with $\left[{ }^{3} \mathrm{H}\right]$ thymidine $(1 \mu \mathrm{Ci} /$ well $)$, incubated an additional $18 \mathrm{~h}$, and the cells harvested using FilterMAT 11731 (SKATRON Instruments, UK) and cell harvester PHD (Cambridge Technology, UK). Incorporated radioactivity was determined as counts per minute by $\beta$ scintillation counting (Packard-1900 CA, US). Lymphocyte proliferation was expressed as stimulation index (SI) and the cut off was fixed at SI $>3$.

IFN- $\gamma$ detection - IFN- $\gamma$ was measured with a standard ELISA, using the Duo-Set-IFN- $\gamma$ kit (R\&D, US), according to manufacturer's recommendations. The concentrations of IFN- $\gamma$ in the samples were calculated with the standard curve generated from recombinant IFN$\gamma$, and results were expressed in picograms. The cut of was fixed at $100 \mathrm{pg} / \mathrm{ml}$.

Statistical analysis - T-cell responses were evaluated non-parametrically using Kruskal Wallis and MannWhitney tests for comparison of study groups. $P \leq 0.05$ was considered statistically significant. Data were reported as mean \pm standard error (SE)

\section{RESULTS}

The immunological reactivity to PPD and recombinant proteins $16 \mathrm{kDa}$, MT10.3, MBP-3, and NarL was evaluated by stimulating PBMC and measuring IFN- $\gamma$ production from TB patients and controls (Table II). As expected, PPD induced a higher positive response and IFN- $\gamma$ release in the majority of the TB patients (87\%) and in TST positive individuals (92\%) as well as in TST negative group (64\%), without significant difference in

TABLE I

Characteristics of Brazilian tuberculous patients and control groups

\begin{tabular}{|c|c|c|c|c|c|c|c|}
\hline Characteristics & Total & Male & Female & TST + & TST - & BCG $(\%)$ & Age $(x \pm S E)$ \\
\hline Patients & 38 & 28 & 10 & - & - & 80 & $39 \pm 3$ \\
\hline \multicolumn{8}{|l|}{ Clinical form: } \\
\hline Pulmonary & 32 & 26 & 6 & - & - & 80 & $41 \pm 3$ \\
\hline Extra-pulmonary $^{a}$ & 6 & 3 & 3 & - & - & 83 & $35 \pm 7$ \\
\hline \multicolumn{8}{|l|}{ Treatment } \\
\hline Untreated & 6 & 5 & 1 & - & - & 83 & $32 \pm 6$ \\
\hline Treated ( 1 to 6 months) & 32 & 23 & 9 & - & - & 83 & $40 \pm 8$ \\
\hline Healthy & 67 & 24 & 43 & 38 & 29 & 80 & $30 \pm 2$ \\
\hline
\end{tabular}

BCG: Bacillus Calmette Guèrin vaccine scar; TST \pm : tuberculin skin test positive $(\geq 5 \mathrm{~mm})$ and negative $(<5 \mathrm{~mm})$; $S E$ : standard error; $\mathrm{x}$ : mean; $a$ : ganglionary TB (3), aortic TB (1), skin TB (1), pleural TB (1). 
the mean level of proliferative response and IFN- $\gamma$ production. Subsequent to PPD, a better response was elicited by $16 \mathrm{kDa}$, which was recognized by $56 \%$ of TB patients and TST positive individuals. This protein was more specific in TST negative control group, been recognized by only $21 \%$ of the individuals ( $p<0.03$ ). Although the mean IFN- $\gamma$ response to $16 \mathrm{kDa}$ in TB patients and control was significantly lower then PPD $(\mathrm{p}<0.05)$, there was a significant difference in the average level of IFN- $\gamma$ among the groups tested, which was obtained exclusively for $16 \mathrm{kDa}(\mathrm{TB} / \mathrm{TST}$ positive $\times$ TST negative, $p=0.015$ ). The MT-10.3 stimulated PBMC from $41 \%$ of TB patient; however the IFN- $\gamma$ production was detected in only $24 \%$, with a mean response close to the cut off. The lowest reactivity in all group tested was obtained with NarL and MBP-3

The effect of chemotherapy on IFN- $\gamma$ and proliferative response was also evaluated in TB patients (Table III). Chemotherapy increased mean responses to PPD, however the frequency of responders was high for both group of patients $(>83 \%)$. 16 kDa was associated with an increase mean reactivity in PBMC responses and frequency of responders in untreated patients, followed by MT-10-.3 that gave the same pattern but with lower responses. None of the responses was significantly different between groups. Sensitivity and specificity values for all antigens were calculated, and although the PPD had $87 \%$ sensitivity the specificity was low $(36 \%)$. On the other hand, only $16 \mathrm{kDa}$ afforded identification of more than $50 \%$ of the patients with specificity of $80 \%$. However if the calculation included the healthy TST positive donors, the specificity decreased to $60 \%$, that is still higher than PPD.

\section{DISCUSSION}

TB control depends on early identification and treatment completion. Several secreted antigens have been characterized, and their utility for diagnostic testing as well as their attributes as vaccine components have been exploited (Bothamley 1995, Lodha \& Kabra 2004, Orme 2006). A very well established knowledge in mycobacterial disease is that a strong $\mathrm{T}$ cell response is associated with localization of and protection against the pathogen. Herein, we investigated the human $\mathrm{T}$ cell response in vitro against $M$. tuberculosis recombinant proteins MPB-3, Narl, MT10.3, $16 \mathrm{kDa}$, and PPD in a TB high endemic area. Our results demonstrated that PBMC from patients and healthy controls did not elicit strong levels of cell proliferation and INF- $\gamma$ release, as did PPD. However, we did not encounter significant difference in PPD induced IFN- $\gamma$ production in patients compared to controls, confirming previous findings (Surcel et al. 1994). As proliferation, in general, correlates with INF- $\gamma$ production, we will solely discuss the data concerning INF- $\gamma$. T cell response from few patients and controls was obtained under MBP-3 and NarL stimulation, reveling that these antigens are not well recognized by host cell immunity. However, the T cells recognized MT-10.3 more specifically since most of the healthy TST negative individuals failed to respond. However a small number of healthy TST positive individuals (17\%) and tuberculous patients (24\%) yielded an in vitro response. This may suggest that MT10.3 is expressed and recognized in some individuals during active infection, which is supported by the fact that $50 \%$ of the untreated patients produced INF- $\gamma$ against only 19\% among those treated (Table III). However, further prospective study must be undertaken in order to confirm this data. The other possibility is that the result merely reflects a cross reaction, as MT-10.3 has high homology with M. bovis and M. avium proteins (Skjot et al. 2002). This may be a misconception because more than $80 \%$ of our sampling (including TST negative controls, which did not recognize this Ag) was vaccinated

\section{TABLE II}

Proliferative response and interferon- $\gamma(\mathrm{INF}-\gamma)$ production by peripheral blood mononuclear cells from tuberculosis (TB) patients and controls groups stimulated with recombinant proteins and PPD

\begin{tabular}{|c|c|c|c|c|c|c|}
\hline \multirow[t]{2}{*}{ Proteins } & \multicolumn{3}{|c|}{$\begin{array}{c}\text { Proliferation }(\mathrm{x} \pm S E) \\
\text { Number of positive/Total }(\%)\end{array}$} & \multicolumn{3}{|c|}{$\begin{array}{c}\text { IFN- } \gamma(\mathrm{x} \pm S E) \\
\text { Number of positive/Total }(\%)\end{array}$} \\
\hline & $\mathrm{TB}$ & TST+ & TST- & $\mathrm{TB}$ & TST+ & TST- \\
\hline PPD & $\begin{array}{c}47.98(14.88) \\
33 / 38(87)\end{array}$ & $\begin{array}{c}35.90(7.24) \\
34 / 37(92)\end{array}$ & $\begin{array}{c}15.57(4,83) \\
18 / 28(64)\end{array}$ & $\begin{array}{c}1.038,13(184.8) \\
33 / 38(87)\end{array}$ & $\begin{array}{c}1.222 .77(147.12) \\
34 / 37(92)\end{array}$ & $\begin{array}{c}696.37(138.5) \\
16 / 28(64)\end{array}$ \\
\hline $16 \mathrm{kDa}$ & $\begin{array}{l}7.3(1.86)^{a} \\
13 / 24(54)\end{array}$ & $\begin{array}{l}4.29(0.9) \\
15 / 27(56)\end{array}$ & $\begin{array}{c}2.72(0,7) \\
4 / 20(20)\end{array}$ & $\begin{array}{c}321(83.07)^{b} \\
13 / 24(54)\end{array}$ & $\begin{array}{c}217.4(40.0)^{b} \\
15 / 27(56)\end{array}$ & $\begin{array}{l}71(21.4) \\
4 / 19(21)\end{array}$ \\
\hline MT-10.3 & $\begin{array}{c}4.20(1.21) \\
15 / 37(41)\end{array}$ & $\begin{array}{c}4.37(1.2) \\
6 / 35(17)\end{array}$ & $\begin{array}{c}2.74(1,01) \\
2 / 26(8)\end{array}$ & $\begin{array}{c}103,78(46.99)^{b} \\
9 / 38(24)\end{array}$ & $\begin{array}{c}75.94(29.34) \\
6 / 35(17)\end{array}$ & $\begin{array}{c}70.83(50.59) \\
2 / 26(8)\end{array}$ \\
\hline NarL & $\begin{array}{l}1.58(0.35) \\
1 / 16(6)\end{array}$ & $\begin{array}{l}1.18(0,2) \\
3 / 23(13)\end{array}$ & $\begin{array}{l}1.58(0.25) \\
2 / 17(12)\end{array}$ & $\begin{array}{l}105.4(102.0) \\
1 / 16(6)\end{array}$ & $\begin{array}{l}40.3(19.86) \\
3 / 23(13)\end{array}$ & $\begin{array}{l}53.56(39.17) \\
2 / 15(13)\end{array}$ \\
\hline MBP-3 & $\begin{array}{c}1.41(0.2) \\
0 / 17(0)\end{array}$ & $\begin{array}{c}1.87(0,51) \\
1 / 25(4)\end{array}$ & $\begin{array}{c}1.52(0.41) \\
3 / 17(18)\end{array}$ & $\begin{array}{c}2.80(2.75) \\
0 / 17(0)\end{array}$ & $\begin{array}{c}8.43(4.46) \\
1 / 25(4)\end{array}$ & $\begin{array}{c}69(34.85) \\
3 / 17(18)\end{array}$ \\
\hline
\end{tabular}

TST \pm : healthy control tuberculin skin test $\geq 5 \mathrm{~mm}$ and $<5 \mathrm{~mm}$, respectively; $a$ : one-way analysis of variance (Kruskal Wallis Multiple Comparison Test): $\mathrm{p}<0.05$, TB x TST-; $b$ : TST+ x TST-; x: mean; SE: standard error. The cut-of for proliferetive response was 3 IS and $100 \mathrm{pg} / \mathrm{ml}$ for IFN- $\gamma$ production. 
TABLE III

Proliferative response and interferon- $\gamma(\mathrm{INF}-\gamma)$ production by peripheral blood mononuclear cells from the tuberculosis patients untreated and treated stimulated with recombinant proteins and PPD

\begin{tabular}{|c|c|c|c|c|}
\hline \multirow{3}{*}{ Proteins } & \multicolumn{4}{|c|}{ TB patients } \\
\hline & \multicolumn{2}{|c|}{$\begin{array}{c}\text { Untreated } \\
\text { Mean } \\
\text { No. +/Total (\%) }\end{array}$} & \multicolumn{2}{|c|}{$\begin{array}{c}\text { Treated } \\
\text { Mean } \\
\text { No. +/Total (\%) }\end{array}$} \\
\hline & Proliferation & IFN- $\gamma$ & Proliferation & IFN- $\gamma$ \\
\hline \multirow[t]{2}{*}{ PPD } & 36.71 & 514.04 & 50.16 & $1.136,40$ \\
\hline & $6 / 6(100)$ & $5 / 6(83)$ & 30/31(97) & $28 / 32(88)$ \\
\hline \multirow[t]{2}{*}{$16 \mathrm{kDa}$} & 14.00 & 505.00 & 5.41 & 269.80 \\
\hline & $3 / 6(50)$ & 4/5 (80) & $9 / 22(41)$ & $9 / 19(47)$ \\
\hline \multirow[t]{2}{*}{ MT-10.3 } & 8.12 & 59.76 & 3.44 & 92.95 \\
\hline & $3 / 6(50)$ & $13 / 6(50)$ & 12/31 (39) & 6/32 (19) \\
\hline \multirow[t]{2}{*}{ NarL } & 2.08 & 8.04 & 1.50 & 121.62 \\
\hline & $0 / 6(0)$ & $0 / 6(0)$ & $2 / 13(15)$ & $1 / 14(7)$ \\
\hline \multirow[t]{2}{*}{ MBP-3 } & 1.25 & 0.65 & 1.44 & 2.97 \\
\hline & $0 / 6(0)$ & $0 / 6(0)$ & $1 / 19(5)$ & $0 / 15(0)$ \\
\hline
\end{tabular}

The cut-off for proliferative response was 3 IS and $100 \mathrm{pg} / \mathrm{ml}$ for IFN- $\gamma$ production.

with BCG. T cell response to MT-10.3 may merely be more specific, although not sensitive, and the responders among TST positive and negative donors may be related to true latent infection. In this investigation MT-10.3 did not prove to be strongly recognized $\mathrm{T}$ cell antigen, corroborating previous studies reporting that the synthetic peptides of this Ag are less reactive than those from its TB10.4 highly homologous protein (Alderson et al. 2000, Skjot et al. 2002).

Antigens such as $16 \mathrm{kDa}$ (former $14 \mathrm{kDa}$ ) have been extensively studied and reported to have pronounced immunogenicity by the presence of specific immunoglobulin in smear positive and negative patients with pulmonary TB. However, the specificity is compromised by the presence of immune reactivity in sera from healthy hospital workers and household contacts of TB patients (Jackett et al. 1988, Bothamley et al. 1992). Improved sensitivity and specificity has been described in extra pulmonary and pediatric TB for $16 \mathrm{kDa}$, suggesting bacilli Ag production in early stage infection (Umadevi et al. $2002,2003)$. In this study the sensitivity and specificity of $\mathrm{T}$ cell response for $16 \mathrm{kDa}$ were $54 \%$ and $60 \%$, respectively. Similar results were obtained with the most reactive synthetic peptide sequence (91-110) of $16 \mathrm{kDa}$, $50 \%$ and $66.7 \%$ (Friscia et al. 1995).

INF- $\gamma$ has been well established as a protective cytokine in animal models of TB. In this study, the in vitro production of INF- $\gamma$ clearly decreased in response to PPD in human TB untreated patients, but was successfully restored after specific therapy. The over time change in $\mathrm{T}$ cell immune response during $\mathrm{TB}$ infection has already been described (Hernandez-Pando \& Rook 1994, Hernandez-Pando et al. 1996, Wilkinson et al. 1998, Ulrichs et al. 2000). Our results for $16 \mathrm{kDa}$ and MT-10.3 responses revealed a tendency to increased $\mathrm{T}$ cell response in untreated patients. Previous work, using the same Ags to investigate the human $\mathrm{T}$ and $\mathrm{B}$ cell immune response disclosed a higher rate of responder in healthy TST + donors than in patients treated $<1$ month (Ulrichs et al. 2000), but in the present study, the frequency of responder in the untreated TB patient group was higher $(80 \%)$ than in the TST+ group $(56 \%)$. However, it has been divulged that prior to therapy, patients phenotypic of CD4 cell clones stimulated with $16 \mathrm{kDa}$ were both $\mathrm{Th}_{1}$ (produced IFN- $\gamma$ ) and predominately $\mathrm{Th}_{0}$ (produced both IFN- $\gamma$ and IL-4) (Caccamo et al. 2005). Thus may support our findings concerning the average level of IFN- $\gamma$ in untreated patients since $16 \mathrm{kDa}$ may quite possibly stimulate both T cell clones to produce IFN- $\gamma$, besides this Ag could be preferentially produced in the early stages of infection.

Recently it has been suggested that $16 \mathrm{kDa}$ can be a good marker for latent infected individuals because $T$ cells from individuals living in endemic area, previously exposed to M. tuberculosis but without any symptoms or known recent exposure to TB, preferentially recognized this protein (Demissie et al. 2006). In our study, opposite to PPD, to which most of TST positive and negative healthy individuals responded, $16 \mathrm{kDa}$ was recognized by only 56 and $21 \%$ of, respectively, TST healthy individuals. Considering that they did not show symptoms or recent contact with TB infected person, this may suggest a pattern of latent infection in these patients.

Our data contribute to the better understanding of the specificity of $\mathrm{T}$ cell response in an endemic area and show that among recombinant proteins tested, $16 \mathrm{kDa}$ is more recognized by active TB untreated patients and in healthy individuals eliciting a more selective immune response than PPD. Gene encoding $16 \mathrm{kDa}$ is over expressed during the stationary growth phase of the TB bacilli (Yuan et al. 1996), so a complementary prospective study in TB patients before and during the treatment and in recent healthy household contacts and 
healthy individuals with previous exposure should be addressed to clarify the diagnostic potential use of this protein.

\section{ACKNOWLEDGMENTS}

To Drs Francisco Eduardo da Rocha Caldeira and Antonio Orlando Resteita and other members of Clinical Analyses Laboratory of Hospital Municipal Souza Aguiar, Rio de Janeiro, Brazil, that provided further laboratory information. To the time from Centro de Saúde, Escola Germano Silval Farias, ENSP-Fiocruz, Rio de Janeiro that supplied patient's medical records information. To Mitchell Raymond Lishon, Native of Chicago, IL, US, for revising this manuscript.

\section{REFERENCES}

Agrewala JN, Wilkinson RJ 1998. Differential regulation of Th1 and Th2 cells by $\mathrm{p} 91-110$ and $\mathrm{p} 21-40$ peptides of the 16-kD alpha-crystallin antigen of Mycobacterium tuberculosis. Clin Exp Immunol 114: 392-397.

Alderson MR, Bement T, Day CH, Zhu L, Molesh D, Skeiky YA, Coler R, Lewinsohn DM, Reed SG, Dillon DC 2000. Expression cloning of an immunodominant family of Mycobacterium tuberculosis antigens using human CD4 (+) T cells. $J$ Exp Med 191: 551-560.

Bothamley GH 1995. Serological diagnosis of tuberculosis. Eur Respir J 8: 676-688.

Bothamley GH, Beck JS, Potts RC, Grange JM, Kardjito T, Ivanyi J 1992. Specificity of antibodies and tuberculin response after occupational exposure to tuberculosis. J Infect Dis 166: 182-186.

Caccamo N, Meraviglia S, Dieli F, Romano A, Titone L, Salerno A 2005. Th0 to Th1 switch of CD4 T cell clones specific from the 16-kDa antigen of Mycobacterium tuberculosis after successful therapy: lack of involvement of epitope repertoire and HLA-DR. Immunol Letter 98: 253-258.

Colditz GA, Brewer TF, Berkey CS, Wilson ME, Burdick E, Fineberg HV, Mosteller F 1994. Efficacy of BCG vaccine in the prevention of tuberculosis. Meta-analysis of the published literature. Jama 271: 698-702.

Demissie A, Leyten EM, Abebe M, Wassie L, Aseffa A, Abate G, Fletcher H,Owiafe P, Hill PC, Brookes R, Rook G, Zumla A, Arend SM, Klein M, Ottenhoff TH, Andersen P, Doherty TM the VACSEL Study Group 2006. Recognition of stagespecific mycobacterial antigens differentiates between acute and latent infections with Mycobacterium tuberculosis. Clin Vaccine Immunol 13: 179-186.

Fine PEM 1995. Variation in protection by BCG: implications of and for heterologous immunity. Lancet 346: 1339-1345.

Friscia G, Vordermeier HM, Pasvol G, Harris DP, Moreno C, Ivanyi J 1995. Human T cell responses to peptide of the 16$\mathrm{kD}$ antigen in tuberculosis. Clin Exp Immunol 102: 53-57.

Guzmán GA, Hernández AJ, Cuevas RZ 2003. Tuberculosis y la importancia de incorporar nuevas metodologías diagnósticas. MEDUNAB 6: 46 -51.

Hernandez-Pando R, Rook GA 1994. The role of TNF-alpha in T-cell-mediated inflammation depends on the Th1/Th2 cytokine balance. Immunology 82: 591-595.

Hernandez-Pando R, Orozcoe H, Sampieri A, Pavon L, Velasquillo C, Larriva-Sahd J, Alcocer JM, Madrid MV 1996. Correlation between the kinetics of Th1, Th2 cells and pathology in a murine model of experimental pulmonary tuberculosis. Immunology 89: 26-33.

Hijjar MA 2005. Tuberculose: desafio permamente. Cad Saúde Públ 21:1-2

Jackett PS, Bothamley GH, Batra HV, Mistry A, Young DB, Ivanyi J 1988. Specificity of antibodies to immunodominant mycobacterial antigens in pulmonary tuberculosis. $J$ Clin Microbiol 26: 2313-2318.

Lodha R, Kabra SK 2004. Newer diagnostic modalities for tuberculosis. Indian J Pediatr 71: 221-227.

Ministério da Saúde 2002. Tuberculose - Guia de Vigilância Epidemiológica, Funasa, Brasília.

Orme IM 2006. Preclinical testing of new vaccines for tuberculosis: a comprehensive review. Vaccine 24: 2-19.

Parish T, Smith DA, Kendall S, Casali N, Bancroft GJ, Stoker NG 2003. Deletion of two-component regulatory systems increases the virulence of Mycobacterium tuberculosis. Infect Immun 71: 1134-1140.

Skjot RL, Brock I, Arend SM, Munk ME, Theisen M, Ottenhoff TH, Andersen P 2002. Epitope mapping of the immunodominant antigen TB10.4 and the two homologous proteins TB10.3 and TB12.9, which constitute a subfamily of the esat6 gene family. Infect Immun 70: 5446-5453.

Surcel HM, Troye-Blomberg M, Paulie S, Andersson G, Moreno C, Pasvol G, Ivanyi J 1994. Th1/Th2 profiles in tuberculosis, based on the proliferation and cytokine response of blood lymphocytes to mycobacterial antigens. Immunology 81 : 171-176.

Ulrichs T, Anding R, Kaufmann SH, Munk ME 2000. Numbers of IFN-gamma-producing cells against ESAT-6 increase in tuberculosis patients during chemotherapy. Int J Tuberc Lung Dis 4: 1181-1183.

Umadevi KR, Ramalingam B, Raja A Dis 2003. Antibody response to Mycobacterium tuberculosis 30 and $16 \mathrm{kDa}$ antigens in pulmonary tuberculosis with human immunodeficiency virus coinfection. Diagn Microbiol and Infect 46: 205-209.

Umadevi KR, Ramalingam B, Rajaindian A 2002. Qualitative and quantitative analysis of antibody response in childhood tuberculosis against antigens of Mycobacterium tuberculosis. J Med Microbiol 20: 145-149.

Urao T, Yamaguchi-Shinozaki K, Shinozaki K 2000. Two-component systems in plant signal transduction. Trends Plant Sci 5: 67-74.

Yuan Y, Crane DD, Barry CE 3rd 1996. Stationary phase-associated protein expression in Mycobacterium tuberculosis: function of the mycobacterial alpha-crystallin homolog. $J$ Bacteriol 178: 4484-4492.

Yuan Y, Crane DD, Simpson RM, Zhu YQ, Hickey MJ, Sherman DR, Barry CE $3^{\text {rd }} 1998$. The 16-kDa alpha-crystallin (Acr) protein of Mycobacterium tuberculosis is required for growth in macrophages. Proc Natl Acad Sci USA 95: 9578-9583.

WHO Report 2002. Global Tuberculosis Control. WHO/CDS/ TB/2001.287 - Surveillance, Planning, Financing, Geneva.

Wilkinson RJ, Wilkinson KA, De Smet KA, Haslov K, Pasvol. G, Singh M, Svarcova I, Ivanyi J. 1998 T- and B-cell reactivity to the $16 \mathrm{kDa}$ alpha-crystallin protein of Mycobacterium tuberculosis. Scandin J Immunol 48: 403-409. 